\title{
The influence of central search task luminance upon peripheral visual detection time
}

\author{
JOSEPH R. ZAHN* \\ San Jose State College, San Jose, Calif. 95114 \\ and \\ RICHARD F. HAINES \\ NASA-Ames Research Center, Moffett Field, Calif. 94035
}

Twenty $S s$ were exposed to a wide range of luminances $(8.5,55,792$, $6,800 \mathrm{fL}$ ) of a centrally located diffuse white search panel. Each $\mathrm{S}$ attempted to detect the onset of seven randomly presented test lights $(90,60,30 \mathrm{deg}$ of arc left and right of 0 deg of arc along the horizontal meridian) concurrently with a continuous search task. The findings suggest that the visual field constricts with an increased central panel luminance. This is shown by an increased peripheral detection time (DT) and by more undetected peripheral test lights, even though the difficulty of the central search task was held constant. These results on the effect of an environmental stressor (high luminance) upon peripheral DT are related to findings from previous investigations as well as various applied situations.

It is reasonably well established that peripheral stimuli are more difficult to detect when attention is focused on simultaneously presented foveal stimuli (Kobrick, 1965; Leibowitz \& Appelle, 1969), when the stimuli are imaged at increasing angular distances from the fovea (Bartz, 1962; Rains, 1963; Haines, 1968), and when the informational load is excessive (Sanders, 1963; Mackworth, 1965). Certain environmental stressors have also been shown to contribute to an increase in detection time (DT) to peripheral stimuli. Bursill (1958), using heat, and Kobrick \& Dusek (1970), using hypoxia, have also demonstrated an increased peripheral DT.

The basis for an increase in peripheral DT has been interpreted as resulting from a "constriction" of attention. Sanders (1963), in summarizing the results of a series of experiments on information processing, refers to the "functional" or "effective" visual field which shrinks or expands depending upon the perceptual load of the task. Similarly, Mackworth (1965) has shown that visual noise causes (functional) tunnel vision where the "useful" field contracts to prevent an overloading. Teichner (1968) has referred to a cortical (attentional) tuning process as a mechanism which has an increased responsiveness to certain stimuli and reduced responsiveness to others. He further states that environmental (physical) stressors and/or symbolic stressors increase the neurophysiological activation level, and, as this level increases, so does the degree of regulatory activity; this leads to

* Now at Department of Physiological Optics, University of Indiana, Bloomington, Ind. 47401 . further selectiveness (i.e., constriction) of attention.

In view of the studies cited above, it was expected that DT to peripheral stimuli would increase with an increase in luminance of a centrally located continuous visual search task when the luminance of the search task panel is high enough to be considered an environmental stressor. Attention is defined as the degree to which a $\mathrm{S}$ can respond successfully to peripherally presented stimuli while also engaged in a central search task; constriction of attention is measured by an increased DT and/or an increased number of errors (i.e., DTs over 2 sec) committed to peripheral test lights.

One must be able to detect and respond to peripheral visual stimuli in a variety of real-life situations (e.g., piloting aircraft, driving surface vehicles, and monitoring many kinds of indicator/control panels). And it is at these times, when a physical stressor is present, that one can least afford to have his peripheral visual detection capability impaired. The purpose of the present investigation is to determine the relationship that exists between a high-luminance stressor, which is also part of the S's central search task panel, and his peripheral visual detection capability.

\section{SUBJECTS}

Twenty paid college students (17 male, 3 female), ranging in age from 18 to 28 years, participated. All had 20:20 uncorrected acuity (Snellen) or better and full and normal visual fields.

\section{APPARATUS}

Peripheral detection was measured by the use of a 24 -in. radius laboratory perimeter, upon which was located seven incandescent red 0.63 -in.-diam (1 deg $30 \mathrm{~min}$ of arc) test lights, each separated by $30 \mathrm{deg}$ of arc along the S's horizontal meridian. Test light luminances were: $90 \mathrm{deg} L$ and $\mathrm{R}=115 \mathrm{fL} ; 60 \operatorname{deg} \mathrm{L}$ and $\mathrm{R}=105 \mathrm{fL}$; $30 \mathrm{deg} L$ and $R=83 \mathrm{fL}$; $0 \mathrm{deg}=95.8 \mathrm{fL} ;$ where $\mathrm{L}=$ left and $\mathrm{R}=$ right of the 0 -deg test light. The interstimulus interval was varied randomly in seven intervals ranging from 6 to $10 \mathrm{sec}($ mean $=8 \mathrm{sec})$.

A diffuse white $17 \times 14$ in. panel was located on the left and right sides (intersecting at a 45- deg angle) of a $14 \times 14$ in. ( $30 \mathrm{deg} 15 \mathrm{~min}$ of arc wide) central white ( $90 \%$ reflectance) panel. The two 30-deg-are test lights and the 0 -deg test light were seen through 1-in.-diam holes made in these three panels. The stimuli used in the central search task consisted of a 5 × 5 matrix of photographically reproduced English alphabet letters. Each of the black letters (letter-to-background contrast $=-.9$ ) were on 2.5 -in. centers (height $=0.08 \mathrm{in}$; width $=0.06$ in.), and at the 24 -in. viewing distance, the stroke and line separation was equivalent to an acuity of 20:200 (10 min of arc). The interletter visual angle, horizontal and vertical, was 6 deg of arc; from one corner letter to the opposite diagonal letter was $30 \mathrm{deg}$ $30 \mathrm{~min}$ of arc and from any diagonal letter to any adjacent letter was $8 \mathrm{deg}$ $27 \mathrm{~min}$ of arc.

\section{PROCEDURE}

Each $S$ viewed the perimeter and central panel from a 24-in. distance within a testing facility described elsewhere (Haines \& Burgard, 1967). A solar simulator $\left(5,800^{\circ} \mathrm{K}\right)$ illuminated the central panel. Neutral filters were inserted in the beam to obtain the following luminances: 55,792 , $6,800 \mathrm{fL}$. Standard fluorescent $\left(3,200^{\circ} \mathrm{K}\right)$ ceiling lamps were used to produce a control panel luminance of $8.5 \mathrm{fL}$.

All Ss responded to the onset of a test light by pressing a normally open spring-loaded switch held in their preferred hand. A Model S-1 Standard Electronic Clock started when the test light came on and stopped with the S's response. DT measurements are accurate to approximately $10 \mathrm{msec}$. The randomized letter presentation order for the search task was pretaped on a Cassette recorder. One letter of the alphabet was called out approximately every $5 \mathrm{sec}$ over the intercom. The $S$ searched for this letter, fixated it for about $1 \mathrm{sec}$, and then refixated the center 0 -deg test light until the next letter was called out. The S's head was positioned by a chinrest, and vision was always binocular. The $\mathrm{S}$ was light-adapted for at least $2 \mathrm{~min}$ to each panel luminance.

Each daily session (160 responses per S) lasted about $20 \mathrm{~min}$. The total number of DT responses collected on all Ss was 11,200 . The presentation order of all conditions was 


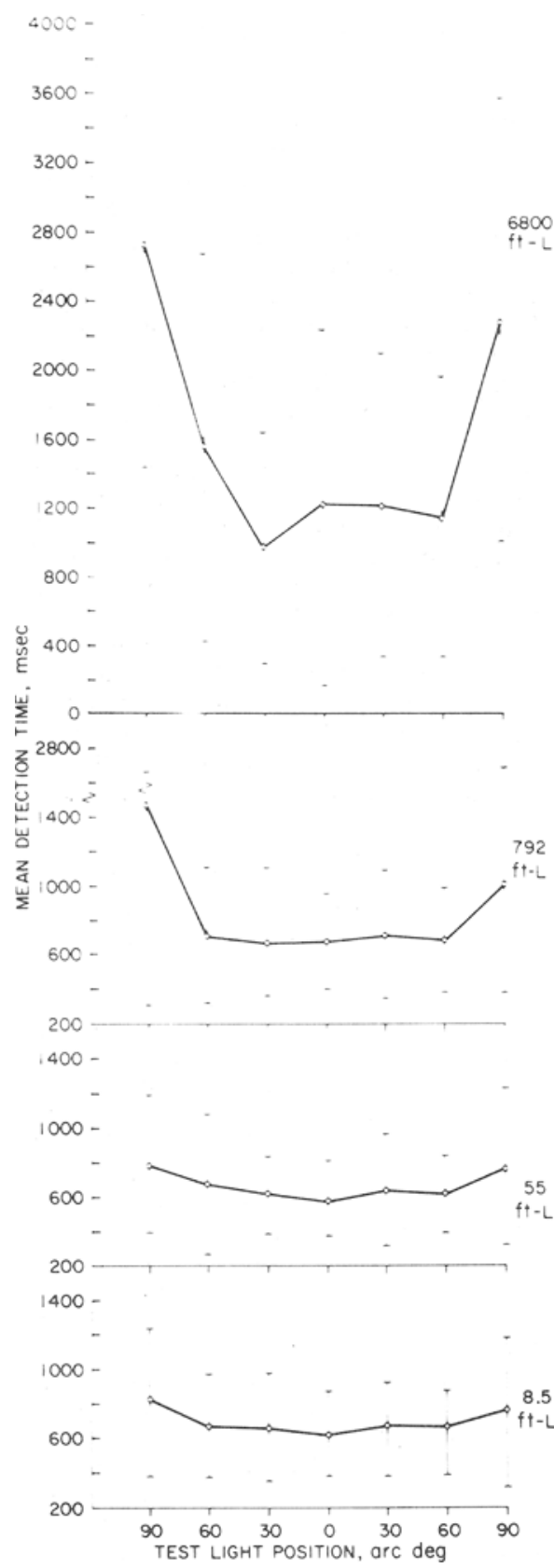

Fig. 1. Mean detection time to peripheral lights under 8.5-, 55-, 792-, and 6,800 -fL luminances.

appropriately counterbalanced to help control for order and learning effects. All Ss were given two complete training sessions just prior to the 4-day experimental data collection.

The $\mathbf{S}$ was told that the lights would appear at any position and at any time during the testing session. It was emphasized that he was to respond as fast as possible to both test light onset and to each letter called out and not to stop performing one task in order to do the other; i.e., the test instructions did not bias $\mathbf{S}$ toward either task.

\section{RESULTS}

The results are presented in Fig. 1. Plus and minus one standard deviation is shown about each DT (in milliseconds). Each DT is based on 400 responses.

The first analysis of variance (Bennett \& Franklin, 1954) performed used a luminance (L) by light position (P) by Ss (S) design and included all test lights. Significant main effects were obtained for luminance, $F(3 / 57)=25.01, p<.001 ;$ for light position, $F(6 / 114)=43.97, p<.001$ and for Ss, $F(19 / 10604)=52.41$, $\mathrm{p}<.001$. The Position by Luminance interaction, $F(18 / 342)=20.75$, $p<.001$, and the Position by Luminance by $S s$ interaction, $F(342 / 10604)=5.15, p<.001$, were also significant. A subsequent Newman-Keuls test indicated that the significant $(p<.01)$ 90-deg light position contributed the majority of the total variance. Therefore, a second analysis of variance was performed which excluded the 90-deg test lights. This analysis showed that the main effects were significant, as was the Position by Luminance by Ss interaction, $F(228 / 7600)=1.57$, $\mathrm{p}<.001$.

It can be seen in Fig. 1 that DT within $60 \mathrm{deg}$ of arc increases slightly on both sides of the 0 -deg test light position. However, $t$ tests showed that mean DTs associated with both $90-\mathrm{deg}$ test light positions differ significantly $(\mathrm{p}<.001)$ from the $0 ., 30-$, and 60-deg arc left and right test light positions. For each of the luminance levels $(55,792,6,800 \mathrm{fL})$, t-test differences were significant (all $p<.001)$. The 8.5-fL condition did not differ significantly from the 55 -fL condition, but did differ significantly from the 792- and 6,800-fL conditions (each $\mathrm{p}<.001)$.

If $\mathrm{S}$ did not respond to the onset of a test light within $2 \mathrm{sec}$, an error was scored. A chi-square analysis was performed on the number of errors which occurred per luminance condition and test light position. The distribution of errors was similar to the distribution of increased DTs for both test light position and panel luminance. Thus, significantly more errors $(p<.005)$ were made to the more peripheral test lights as well as under the higher luminance conditions. The percentage of errors, disregarding the 0 -deg arc test light position and summed across test light positions, increased regularly as a function of luminance; i.e., $8.5 \mathrm{fL}$ (1\%), $55 \mathrm{fL}(2 \%), 792 \mathrm{fL}(5 \%)$, and $6,800 \mathrm{fL}(27 \%)$.

Each S's daily data were also analyzed in five equal-sized groups. The grand mean for each group was determined for the entire study and for each luminance condition. A progressive decrease in DTs across these five groups might be interpreted as a learning (and lengthened DTs as a fatigue) effect. Neither was found. DISCUSSION

The distribution of DTs found in this study is similar to those reported elsewhere (Bursill, 1958; Bartz, 1962; Rains, 1963; Kobrick, 1965; Kobrick \& Dusek, 1970). The present error analysis showed that Ss frequently and regularly missed test lights at the far periphery and even missed the 0 -deg test light $(15 \%$ at $6,800 \mathrm{fL})$ which was centered on the search panel. Further experimentation, including eye movement monitoring during the search task, should be conducted to help clarify this finding.

The present panel luminances were shown to produce regular changes in DT in a manner similar to those associated with the presence of an environmental stressor, and attention under these conditions was shown to constrict. This is a finding consistent with Teichner's (1968) theory.

As mentioned earlier, these lengthened DTs and the increased percentage of missed test lights could have serious implications if they occur in a number of real-life situations, particularly those activities which require continued central vigilance as well as peripheral visual detection in the presence of a brightly illuminated panel. Based upon the present findings, it is reasonable to suggest that warning lights should be located within $60 \mathrm{deg}$ of arc or less from the line of sight (along the horizontal meridian) in order to aid detection as fast as possible.

To summarize, it is suggested, on the basis of experimental results, that peripheral visual performance may be impaired during situations of high luminance. This effect, as well as the effect of other stressors, i.e., hypoxia, acceleration, etc., should be taken into account and subsequent research conducted to define the mechanisms which underlie impaired peripheral visual performance as well as to determine how best to counteract this effect.

\section{REFERENCES}

BARTZ, A. E. Eye movement latency, duration and response time as a function of angular displacement. Journal of Experimental Psychology, 1962, 64, 318-324.

BENNETT, C. A., \& FRANKLIN, N. L. Statistical analysis in chemistry and the chemical industry. New York: Wiley, 1954.

BURSILL, A. E. The restriction of peripheral vision during exposure to hot and humid conditions. Quarterly Journal of Experimental Psychology, 1958, 10, 113-129.

HAINES, $R, F$. Detection time to a point source of light appearing in a star field background with and without a glare source present. Human Factors, 1968, 10. 523-529. 
HAINES, R. F. \& BURGARD, J, P. Unique NASA high luminance rision lab uses CC techniques. Joumal of Contamination Control, 1967, 6, 26-29.

KOBRICK, J.L. Effects of physical location of visual stimuli on intentional response time. Journal of Engineering Psychology $1965,1,1-8$.

KOBRICK, J, L., \& DUSEK, E. R. Effects of hypoxia on voluntary response time to peripherally located risual stimuli. Journal of Applied Psychology, 1970, 29. 4, 444-448.

LEIBOWITZ, H. W., \& APPELLE, S. The effect of a central task on luminance thresholds for peripheraliy presented stimuli. Human Factors, $1969,11$. 387-392.

MACKWORTH, N. H. Visual noise causes tunnel vision. Psychonomic Science. $1965,3,67-68$
RAINS, J. D. Signal luminance and position effects in human reaction time. Vision Research, 1963, 3, 239-251.

SANDERS, A, F. The selective process in the functional visual field. Institute for Perception, RVO-TNO, Soesterberg, The Netherlands, 1963.

TEICHNER, W. H. Interaction of behavioral and physiological stress reactions Psychological Review, 1968, 75, 271-291.

\section{CURRENT LITERATURE ON HUMAN VISION}

ANDERSSON, A. L. (Psychological Laboratory, Lund University, Sweden), \& RUUTH, E. Relation between spiral aftereffect duration and rod-and-frame test performance in early childhood. Perceptual and Motor Skills, 1971, 32, 843-849.

CHANCE, J. E. (University of Missouri, Columbia, Mo. 65201), \& G O L D S T E I N, A. G. Internal-external control of $r e i n f o r c e m e n t$ a $n d$ embedded-figures performance. Perception \& Psychophysics, 1971, 9, 33-34.

COMALLI, P. E. (Temple University, Philadelphia, Pa. 19122), \& ALTSHULER, M. W. Effect of body tilt on auditory localization. Perceptual and Motor Skills, 1971, 32, 723-726.

DEICH, R. F. (California Department of Mental Hygiene, Pacific State Hospital, Pomona, Calif. 91768). Children's perception of differently oriented shapes: Word recognition. Perceptual and Motor Skills, 1971, $32,695-700$.

KLAPPER, Z. S. (Albert Einstein College of Medicine, Bronx, N.Y.), \& BIRCH, H. G. Developmental course of temporal patterning in vision and audition. Perceptual and Motor Skills, 1971, 32, 547-555.

LANDERS, W. F. (Texas Tech University, Lubbock, Tex. 79406), COGAN, D. C., \& HART, R. R. Developmental changes in the perception of inverted triangular forms: Closure and order effects. Perceptual and Motor Skills, 1971, 32, 587-592.

MARKS, L. E. (John B. Pierce Foundation Laboratory and Yale School of Medicine, New Haven, Conn. 06520). Brightness and retinal locus: Effects of target size and spectral composition. Perception \& Psychophysics, 1971, 9, 26-30.

MATTHEWS, M. L. (University of Guelph, Guelph, Ontario, Canada). Spatial and temporal factors in masking by edges and disks. Perception \& Psychophysics, 1971, 9, 15-22

MORF, M. E. (University of Windsor, Windsor, Ontario, Canada), KA VA NA UGH , R . D., \& McCONVILLE, M. Intratest and sex differences on a portable rod-and-frame test. Perceptual and Motor Skills, 1971, 32, 727-733.

MORRIS, B. B. (Purdue University,
Indianapolis, Ind. 46205). Effects of angle, sex, and cue on adults' perception of the horizontal. Perceptual and Motor Skills, 1971, 32, 827-830.

PURCELL, D. G. (New School for Social Research, 66 West 12th Street, New York, N.Y. 10011), \& STEWART, A. L. The two-flash threshold: An evaluation of critical-duration and visual-persistence hypothesis. Perception \& Psychophysics, 1971 , 9,61-64.

RESTLE, F. (Indiana University, Bloomington, Ind. 47401). Instructions and the magnitude of an illusion: Cognitive factors in the frame of reference. Perception \& Psychophysics, 1971, 9, 31-32.

SMITH, G. J. W. (Lund University, Sweden), \& SJOEHOLM, L. Projected afterimages after manipulation of cognitive schemes in adults. Perceptual and Motor Skills, 1971, 32, 899-904.

WEERTS, T. C. (University of Wisonsin, Madison, Wis. 53706), \& THURLOW, W. R. The effects of eye position and expectation on sound localization. Perception \& Psychophysics, 1971, 9, 35-39. 


\section{CURRENT LITERATIRE ON HUMAN VISION}

AREND, L. E., BUEHLER, J. N., \& LOCKHEAD, G. R. Difference information in brightness perception. Perception \& Psychophysics, 1971, 9, 367-370.

BORJESSON, E. (University of Uppsala, Uppsala, Sweden). Properties of changing patterns evoking visually perceived oscillation. Perception \& Psychophysics, 1971, 9, 303-308.

CHAP \NIS, A. (The Johns Hopkins Unuversity, Baltimore, Md. 21218), \& OVERBEY, C. M. Absolute judgments of colors using natural color names. Perception \& Psychoph: sics, 1971, 9, 356-360.

COR B ALLIS, M. C. (McGill University, Montreal 110, P. Q., Can ada), \& LUTHE, L. Two-channel visual memory. Perception \& Psychophysics, 1971, 9, 361-367.
DAWSON, W. E. (University of Notre Dame, Notre Dame, Ind. 46556). Magnitude estimation of apparent sums and differences. Perception \& Psychophysics, 1971, 9, 368-374.

DOOST, R., \& TURVEY, M. T. (University of Connecticut, Storrs, Conn. 06268). Iconic memory and central processing capacity. Perception \& Psychophysics, 1971, 9, 269-274.

EGETH, H. (The Johns Hopkins University, Baltimore, Md. 21218). Laterality effects in percpetual matching. Perception \& Psychophysics, 1971, 9, 375-376.

GOGEL, W. C. (University of California, Santa Barbara, Calif. 93106). The validity of the size-distance invariance hypotheses with cue reduction. Perception \& Psychophysics, 1971, 9, 92-94.

KERR, J. L. (University of Pittsburgh
School of Medicine, Pittsburgh, $\mathrm{Pa}$. 15213). Visual resolution in the periphery. Perception \& Psychophysies, 1971, 9, 375-378.

KIETZMAN, M. L. (Biometric Research, New York, N.Y. 10032), BOYLE, R. C., \& LINDSLEY, D. B. Perceptual masking: Peripheral vs central factors. Perception \& Psychophysics, 1971, 9, 350-352.

WAIBEL, H. (Western Washington State College, Bellingham Wash. 98225), \& THOMPSON, R. W. The effects of instructions, fixed rate of presentation, and complexity on free looking time. Percpetion \& Psychophysics, 1971, 9, 377-378.

WEISSTEIN, N. (Loyola University, Chicago, Ill. 60626), W-shaped and $\mathrm{U}$-shaped functions obtained for monoptic and dichoptic disk-disk masking. Perception \& Psychophysics, 1971, 9, 275-278.

\section{CURRENT LITERATURE ON VERBAL LEARNING}

BOWEN, J. H. (State University of New York at Albany, Albany, N.Y. 12203). Relational mnemonics in category clustering: The correlates of word frequency, familiarity, and category-name variables. Psychonomic Science, 1971, 22, 327-328.

CARROLL, D. (Australian National University, Canberra, A.C.T., Australia), \& HORNE, P. V. Semantic and acoustic labeling. Psychonomic Science, 1971, 22, 241-242.

CAVANAGH, J. P. (Carnegie-Mellon University, Schenley Park, Pittsburgh, Pa. 15213), \& PARKMAN, J. A comparison of the study-recall and anticipation methods in steady state paired-associate learning. Psychonomic Science, 1971, 22, 361-362.

DELPRATO, D. J. (Eastern Michigan University, Ypsilanti, Mich. 48197), \& HUDSON, R. L. Association by contiguity: Clustering in free recall. Psychonomic Science, 1971, 22, 98-99.

DUYNE, H. J. V. (Northern Illinois University, DeKalb, Ill. 60115). The facilitating effects of various training methods on the development of verbal control of nonverbal behavior in four-year-old children. Psychonomic Science, 1971, 22, 345-346.

ELMES, D. G. (Washington and Lee University, Lexington, Va. 24450), \& WILKINSON, W. C. Cued forgetting in free recall: Grouping on the basis of relevance and category membership. Journal of Experimental Psychology, 1971, 87, 438-440.

FULKERSON, F. E. (Western Illinois University, Macomb, Ill. 61455), \& JOHNSON, J. E. Methodological variables in verbal discrimination learning. Psychonomic Science, $1971,22,68-69$.

GORFEIN, D. S. (New College, Sarasota, Fla. 33578). Are good subjective organizers good paired-associate learners? Psychonomic Science, 1971, 22, 340.

HOUSTON, B. K. (University of Kansas, Lawrence, Kans. 66044). Noise, negative transfer, and meaningfulness. Psychonomic Science, 1971, 22, 255-256.

LeBOW, M. D. (University of Manitoba, Winnipeg, Manitoba, Canada), \& TRITT, J. I n t r a d i m e n i onal and extradimensional shifts using a total change design with "word stimuli. Psychonomic Science, 1971, 22, 325-327.
MacDOUGALL, J. C. (Institute for Research in Human Abilities, Memorial University, St. John's, New foundland, Canada). Psychonomic Science, 1971, 22, 347-349.

MEDIN, D. L. (Rockefeller University, New York, N.Y. 10021), \& ROBBINS, D. Effects of frequency on transfer performance after successive discrimination training. Journal of Experimental Psychology, 1971, 87, 434-436.

PAIVIO, A. (University of Western Ontario, London, Ontario, Canada), \& SMYTHE, P. C. Word imagery, frequency, and meaningfulness in short-term memory. Psychonomic Science, 1971, 22, 333-334.

SMITH, R. E. (University of Washington, Seattle, Wash. 98105). Observational learning of modeled responses under shock-avoidance conditions as a function of attitude similarity and attraction toward the model. Psychonomic Science, 1971, 22, 123-124.

SOUCAR, E. (Temple University, Philadelphia, Pa. 19122), WOLK, S., \& COVERT, R. Effects of rewarded interpolated tasks upon short-term retention. Psychonomic Science, $1971,22,321-323$. 


\section{CURRENT LITERATURE ON HUMAN MEMORY}

ANDERS, T. R. (Harvard Medical School, Boston, Mass. 02114), \& LILLYQUIST, T. D. Retrieval time in forward and backward recall. Psychonomic Science, 1971, 22, 205-206.

BOWEN, J. H. (State University of New York at Albany, Albany, N.Y. 12203). Relational mnemonics in category clustering: The correlates of word frequency, familiarity, and cat egory-name variables. Psychonomic Science, 1971, 22, 327-328.

COKE, E. U. (Bell Telephone Laboratories, Murray Hill, N.J. 07974). The effects of test events and spaced practice on free recall learning. Psychonomic Science, $1971,22,335-336$.

DAVES, W. F. (Georgia State University, Atlanta, Ga. 30303), \& RINN, R. C. Free recall of object categories as a function of number of presentations of varied or repeated specimens. Psychonomic Science, 1971, 22, 203-205.

DAVES, W. F. (Georgia State University, Atlanta, Ga. 30303), \& RINN, R. C. The variety effect in free recall as a function of prerecall activity. Psychonomic Science, $1971,22,226-227$.
GRONINGER, L. D. (University of Maryland, Baltimore County, Baltimore, Md. 21228). Mnemonic im a gery and forgetting. Psychonomic Science, 1971, 23, 161-163.

LOFTUS, E. F. (New School for Social Research, New York, N.Y. 10011). Memory for intentions: The effect of presence of a cue and interpolated activity. Psychonomic Science, 1971, 23, 315-316.

MUELLER, J. H. (University of Missouri, Columbia, Mo. 65201), J A B L O N S KI, E. M ., \& FULKERSON, F. E. Clustering in free recall following verbal-discrimination learning. Psychonomic Science, 1971, 23, 163-165.

PAIVIO, A. (University of Western Ontario, London, Ontario, Canada), \& SMYTHE, P. C. Word imagery, frequency, and meaningfulness in short-term memory. Psychonomic Science, $1971,22,333.334$.

SHAPIRO, S. I. (University of Hawaii, Honolulu, Hawail 96822), \& MOELY, B. E. Free recall, subjective organization, and learning to learn at three age levels. Psychonomic Science, 1971, 23, 189.191.
SILVERSTEIN, C., \& GLANZER, M. (New York University, New York, N.Y. 10003). Concurrent task in free recall: Differential effects of LTS and STS. Psychonomic Science, 1971, 22, 367-368.

SMALLWOOD, R. A. (University of Richmond, Richmond, Va. 23173), \& TROMATER, L. J. Acoustic interference with redundant elements. Psychonomic Science, $1971,22,354-357$.

SOUCAR, E. (Temple University, Philadelphia, Pa. 19122), WOLK, S., \& COVERT, R. Effects of rewarded interpolated tasks upon short-term retention. Psychonomic Science, 1971, 22, 321-323.

THURM, A. T. (New York University, New York, N.Y. 10003), \& GLANZER, M. Free recall in children: Long-term store vs short-term store. Psychonomic Science, 1971, 23, 175-176.

WICKELGREN, W. A. (University of Oregon, Eugene, Oreg. 97403), \& NORMAN, D. A. Invariance of forgetting rate with number of repetitions in verbal short-term recognition memory. Psychonomic Science, 1971, 22, 363-364.

\section{CURRENT LITERATURE ON REINFORCEMENT IN HUMAN LEARNING}

CHANCE, J. E. (University of Missouri, Columbia, Mo. 65201), \& G O L D S T E I N, A. G. Internal-external control of r e i n f orce me $\mathrm{n}$ a $\mathrm{n} d$ embedded-figures performance. Perception \& Psychophysics, 1971, 9, 33-34.

GUTHRIE, J. T. (Johns Hopkins University, Baltimore, Md. 21218). Feedback and sentence learning. Journal of Verbal Learning \& Verbal Behavior, 1971, 10, 23-28.

HINES, G. H. (Falcon Management Consultants Ltd., 10 Dryden Chambers, 199 Oxford Street, London WIR, IPA, England). Effectiveness of social and nonsocial reinforcers in a probability learning task. Psychonomic Science, 1971, 23, 411-413.

LINDSKOLD, S. (Ohio University, Athens, Ohio 45701), TEDESCHI,
J. T., BONOMA, T. V., \& SCHLENKER, B. R. Reward power and bilateral communication in conflict resolution. Psychonomic Science, 1971, 23, 415-416.

LOMBARDO, J. P. (University of Oklahoma, Norman, Okla. 73069), WEISS, R. F., \& STICH, M. H. Interpersonal attraction as a function of amount of information supporting the subject's opinions. Psychonomic Science, 1971, 24, 79-80.

MAXWELL, W. A., MILLER, F. D., \& MEYER, P. A. (University of South Dakota, Vermillion, S. Dak, 57069). The relationship between punishment and unavoidability in eliminating avoidance behavior in humans. Psychonomic Science, $1971,23,435-436$.

REBER, A. S. (Brooklyn College, City University of New York, Brooklyn,
N.Y. 11210), \& MILLWARD, R. B. Event tracking in probability learning. American Journal of Psychology, 1971, 84, 85-99.

SINGH, D. (University of Texas at Austin, Austin, Tex. 78712). Effect of level of manifest anxiety and type of pretraining on timing behavior. American Journal of Psychology, 1971, 84, 134-139.

TIMMONS, B. A. (University of Victoria, Wellington, New Zealand). Sex as a factor influencing sensitivity to delayed auditory feedback. Perceptual \& Motor Skills, 1971, 32, 824-826.

WARM, J. S. (University of Cincinnati, Cincinnati, Ohio 45221), HAGNER, G. L., \& MEYER, D. The partial reinforcement effect in a vigilance task. Perceptual \& Motor Skills, 1971, 32, 987-993. 


\section{CURRENT LITERATURE ON INFORMATION PROCESSING}

ALDEN, D. G. (Systems and Researck Center, Honeywell, Inc., Minneapolis, Minn. 55113), WEDELL, J. R., \& KANARICK, A. F. Redundant stimulus coding and keeping-track performance. Psychonomic Science, 1971, 22, 201-202.

BELLER, H. K. (State University of New York, Collegi at Brockport, Brock port, N.Y. 14420). Priming: Effects of advance information on matching. Journal of Experimental Psycholos, 1971, 87, 176-182.

CHECKOSKY, S. F. (Lake Forest College, Lake Forest, Ill. 60045). Speeded classification of multidim. sional stimuli. Journal of Experime al Psychology, 1971, 87, 383-388.

DODD, D. H. (University of Utah, Salt Lake City, Utah 84112), KINSMAN, R. A., KLIPP, R. D., \& BOURNE, L. E., JR. Effects of logic pretraining on conceptual rule learning. Journal of Experimental Psychology, 1971, 88, 119-122.

HALPIN, S. M. (U.S. Army Research Institute of Environmental Medicine, Natick, Mass. 01760), STREUFERT, S., STEFFEY, J., \& LANHAM, N. Information load, proportion of relevance, and relevance perception. Psychonomic Science, 1971, 23, 404-406.

HATTON, D. E., SNORTUM, J. R. (Claremont Men's College, Claremont, Calif. 91711), \& OSKAMP, S. The effects of biasing information and dogmatism upon witness testimony. Psychonomic Science, 1971, 23, 425-427.

MURRAY, F. S. (Randolph-Macon Woman's College, Lynchburg, Va. 24504). Multiple probable situation: A study of a five one-armed bandit problem. Psychonomic Science, 1971, 22, 247-249.

PAYNE, J. W., \& BRAUNSTEIN, M. L. (School of Social Sciences, University of California, Irvine, Calif. 92664). Preferences among gambles with equal underlying distributions. Journal of Experimental Psychology, 1971, 87, 13-18.

ROYER, F. L. (Veterans Administration Hospital, Brecksville, Ohio 44141). Information processing of visual figures in the digit symbol substitution task. Journal of Experimental Psychology, 1971, 87, 335-342.

SNAPPER, K. J. (Engineering
Psychology Laboratory, Institute of Science and Technology, University of Michigan, Ann Arbor, Mich. 48105), \& FRYBACK, D. G. Inferences based on unreliable reports. Journal of Experimental Psychology, 1971, 87, 401-404.

SNAPPER, K. J. (Engineering Psychology Laboratory, Institute of Science and Technology, University of Michigan, Ann Arbor, Mich. 48105), \& PETERSON, C. R. Information seeking and data diagnosticity. Journal of Experimental Psychology, 1971, 87, 429-433.

WALLSTEN, T. S. (L. L. Thurstone Psychometric Laboratory, University of North Carolina, Chapel Hill, N.C. 27514). Subjectively expected utility theory and subjects' probability estimates: Use of measurement-free techniques. Journal of Experimental Psychology, 1971, 88, 31-40.

ZERDY, G. A. (Computer Science Center, University of Maryland, College Park, Md. 20742). Incidental retention of recurring words presented during auditory monitoring tasks. Journal of Experimental Psychology, 1971, 88, 82-89.

\section{CURRENT LITERATURE ON PERFORMANCE}

BARTZ, A. E. (Concordia College, Moorhead, Minn. 56560). Reaction time as a function of stimulus uncertainty on a single trial. Perception \& Psychophysics, 1971, 9, 95-96.

BLACKWELL, P. J. (Texas Tech University, Lubbock, Tex. 79406), \& BELT, J. A. Effect of differential levels of ambient noise on vigilance performance. Perceptual \& Motor Skills, 1971, 32, 734.

BOSWELL, J. J. (University of Missouri, St. Louis, Mo. 63121). Effects of three levels of interpolated activity on the acquisition of a simple motor skill. Perceptual \& Motor SKills, 1971, 32, 35-42.

CAFFREY, B. Department of Social Sciences, Clemson University, Clemson, S.C. 29631), JONES, J. D., \& HINKLE, B. R. Variability in reaction times of normal and educable mentally retarded children. Perceptual \& Motor Skills,
$1971,32,255-258$.

CHANCE, J. E. (University of Missouri, Columbia, Mo. 65201), \& G O L D S T E I N, A. G . Internal-external control of reinforce me $n t$ a $n d$ embedded-figures performance. Perception \& Psychophysics, 1971, 9, 33-34,

DARGEL, R. (Southwest Baptist College, Bolivar, Mo. 65613), \& KIRK, R. E. Manifest anxiety, field dependency, and task performance. Perceptual \& Motor Skills, 1971, 32, 383-393.

HALCOMB, C. G. (Texas Tech University, Lubbock, Tex. 79401), MCFARLAND, B. P., \& DENNY, N. R. Monitoring performance with a time-shared memory task. Perceptual \& Motor Skills, 1971, 32, 347-351.

MC CONCHIE, R. D. (New York State Psychiatric Institute and College of Physicians and Surgeons, Columbia University, New York, N.Y. 10027),
\& RUTSCHMANN, J. Human time estimation: On differences between methods. Perceptual \& Motor Skills, $1971,32,319-336$.

PABEN, M. (Southeast Missouri State College, Cape Girardeau, Mo. 63701), \& ROSENTSWIEG, J. Control of muscular tension in learning a novel gross motor skill. Perceptual \& Motor Skills, 1971, 32, 556-558.

SIMPSON, W. E. (SUNY, College at Oswego, Oswego, N.Y. 13126), VAUGHT, G. M., \& HAM, M. L. Intercorrelations among imagery tasks. Perceptual \& Motor Skills, 1971, 32, 249-250.

WARNER, H. D. (University of Missouri, Rolla, Mo. 65401), \& HEIMSTRA, N. W. Effects of intermittent noise on visual search tasks of varying complexity. Perceptual \& Motor Skills, 1971, 32, 219-226. 


\section{CURRENT LITERATURE ON HUMAN VISION}

AIKEN, L. S. (Temple University, Philadelphia, $\mathrm{Pa}$. 19122), \& BROWN, D. R. A feature utilization analysis of the perception of pattern class structure. Perception \& Psychophysics, 1971, 9, 279-283.

BRADSHAW, J. L. (Monash University, Clayton, Victoria 3168 , Australia), \& WALLACE, G. Models for the processing and identification of faces. Perception \& Psychophysics, 1971, 9, 443-448.

COLE, E. (Simon Fraser University, Vancouver, British Columbia, Canada), \& DIAMOND, A. L. Amount of surround and test-inducing separation in simultaneous brightness contrast. Perception \& Psychophysics, 1971, 9, 125-128.

KULIKOWSKI, J. J. (Physiological Laboratory, Cambridge CB2 3EG, England). Effect of eye movements on the contrast sensitivity of spatio-temporal patterns. Vision Research, 1971, 11, 261-273.

LACK, L. C. (Flinders University of
South Australia, Bedford Park, South Australia 5042). The role of accomodation in the control of binocular rivalry. Perception \& Psychophysics, 1971, 10, 38-42.

LEIBOWITZ, H. W. (Pennsylvania State University, University Park, Pa. 16802), \& SACCA, E. J. Comparison of matching and drawing in the perception of shape at various intelligence levels. Perception \& Psychophysics, 1971, 9, 407-409.

MELLERIO, J. (Department of Physiological Optics, Institute of Opthalmology, Judd St., London WCIH 9QS, England). Light absorption and scatter in the human lens. Vision Research, 1971, 11, 129-141.

RICHARDS, W. (Massachusetts Institute of Technology, Cambridge, Mass. 02139), \& MILLER, J. F. The corridor illsuion. Perception \& Psychophysics, 1971, 9, 421-423.

STONE, G. C. (Langley Porter Neuropsychiatric Institute, San
Francisco, Calif. 94122). Response latencies in visual search involving redundant or irrelevant information. Perception \& Psychophysics, 1971, 9, 9-14.

WEINTRAUB, D. J. (University of Michigan, Ann Arbor, Mich. 48104), \& VIRSU, V. The misperception of angles: Estimating the vertex of converging line segments. Perception \& Psychophysics, 1971, 9, 5-8.

WHITE, K. G. (University of Otago, Dunedin, New Zealand). Zöllner illusion as perceptual enlargement of acute angle. Psychonomic Science, 1971, 24, 73-75.

YOUNG, R. W. (Department of Anatomy and the Jules Stein Eye Institute, University of California at Los Angeles, Center for the Health Sciences, Los Angeles, Calif. 90024). An hypothesis to account for a basic distinction between rods and cones. Vision Research, 1971, 11, 1-5.

\section{CURRENT LITERATURE ON PSYCHOPHYSICS}

AUERBACH, C. (Yeshiva University, New York, N.Y. 10033). An elementary derivation of Stevens' law and Fechner's law from first principles. Perceptual \& Motor Skills, 1971, 32, 361-362.

BUTLER, R. A. (Department of Surgery, University of Chicago, Chícago, IIl. 60637). The monaural localization of tonal stimuli. Perception \& Psychophysics, 1971, 9, 99-101.

CAUTHEN, N. R. (University of Georgia, Athens, Ga. 30601), \& BOARDMAN, W. K. Body boundary and stimulus enhancement. Perceptual \& Motor Skills, 1971, 32, 559-563.

DAVIS, P. (Medfield Foundation, Medfiled, Mass. 02050), \& SILVER, M. J. Ellipse discrimination: A psychophysical task useful for studying incidental stimulation. Perceptual \& Motor Skills, 1971, 32, 95-97.

GOLDNER, J. (Lamont Geological Observatory, Palisades, N.Y. 10964), REUDER, M. E., RIBA, B., \& JARMON, D. Neutral vs ego-orienting instructions: Effects on judgments of magnitude estimation. Perception \&
Psychophysics, 1971, 9, 84-88.

LONG, G. M. (University of Detroit, Detroit, Mich. 48221), \& MO, S. S. Interaction of arousal and task difficulty upon perceptual restriction. Perceptual \& Motor Skills, 1971, 32, 259-264.

MARKS, L. E. (John B. Pierce Foundation Laboratory and Yale School of Medicine, New Haven, Conn. 06520). Brightness and retinal locus: Effects of target size and spectral composition. Perception \& Psychophysics, 1971, 9, 26-30.

MC CONCHIE, R. D. (New York State Psychiatric Institute and College of Physicians and Surgeons, Columbia University, New York, N.Y. 10027), \& RUTSCHMANN, J. Human time estimation: On differences between methods. Perceptual \& Motor Skills, 1971, 32, 319-336.

MOSKOWITZ, H. R. (U.S. Army Natick Laboratories, Natick, Mass. 01760). Intensity scales for pure tastes and for taste mixtures. Perception \& Psychophysics, 1971, 9. 51-56.

POLLACK, I. (Mental Health Research Institute, University of Michigan, Ann Arbor, Mich. 48104).
Discrimination of restrictions in sequentially-encoded auditory displays: Block designs. Perception \& Psychophysies, 1971, 9, 57-60.

PURCELL, D. G. (New School for Social Research, 66 West 12th St., New York, N.Y. 10011), \& STEWART, A. L. The two-flash threshold: An evaluation of criticalduration and visual-persistence hypotheses. Perception \& Psychophysics, 1971, 9, 61-64.

RESTLE, F. (Indiana University, Bloomington, Ind. 47401). Instructions and the magnitude of an illusion: Cognitive factors in the frame of reference. Perception \& Psychophysics, 1971, 9, 31-32.

RULE, S. J. (University of Alberta, Edmonton, Alberta, Canada), \& MARKLEY, R. P. Subject differences in cross-modality matching. Perception \& Psychophysics, 1971, 9, 115-117.

WARD, L. M. (Duke University, Durham, N.C. 27706), \& LOCKHEAD, G. R. Response system processes in absolute judgment. Perception \& Psychophysics, 1971, 9, 73-78. 


\section{CURRENT LITERATURE ON HUMAN MEMORY}

ANDERSON, R. C. (University of Illinois, Urbana, Ml. 61801), \& W A T T S, G. H. Response competition in the forgetting of paired associates. Journal of Verbal Learning and Verbal Behavior, $1971,10,29-34$.

BADDELEY, A. D. (Experimental Psychology Laboratory, University of Sussex, Brighton, England), \& SCOTT, D. Word frequency and the unit sequence interference hypothesis in short-term memory. Journal of Verbal Learning and Verbal Behavior, 1971, 10, 35-40.

BANKS, W. P. (Pomona College, Claremont, Calif. 91711). Confidence-rated recall, $d_{r}$, and tests of Bernbach's finite-state theory in recall. Psychological Bulletin, 1971, 76, 151-152.

BEGG, I. (University of Western Ontario, London 72, Ontario, Canada). Recognition menory for sentence meaning and wording. Journal of Verbal Learning and Verbal Behavior, 1971, 10,
176-181.

BER NBACH, H. A. (Cornell University, Ithaca, N.Y. 14850). Invariance of $d^{*}$ in memroy: Response to Banks. Psychological Bulletin, 1971, 76, 149-150.

KAPLAN, I. T. (New York University Medical Center, New York, N.Y. 10016), \& CARVELLAS, T. Effect of context on verbal recall. Journal of Verbal Learning and Verbal Behavior, 1971, 10, 207-212.

MADIGAN, S. A. (University of Southern California, Los Angeles, Calif, 90007), \& MCCABE, L. Perfect recall and total forgetting: A problem for models of short-term memory. Journal of Verbal Learning and Verbal Behavior, $1971,10,101-106$.

TULVING, E. (Yale University, New Haven, Conn. 06510), \& THOMSON, D. M. Retrieval processes in recognition memory: Effects of associative context. Journal of Experimental Psychology, 1971, 87, 116-124. von WRIGHT, J. M. (University of Turku, Turku, Finland). Effects of distributed practise and distributed recall tests on later recall of paired associates. Jounral of Verbal Learning and Verbal Behavior, $1971,10,311-315$.

WEARING, A. J. (Yale University, New Haven, Conn. 06510), \& CROWDER, R. G. Dividing attention to study sentence acquisition. Journal of Verbal Learning and Verbal Behavior, 1971, 10, 254-261.

WICHAWUT, C. (University of Michigan, Ann Arbor, Mich. 48104 ), \& MARTIN, E. Independence of $A \cdot B$ and $A \cdot C$ associations in retroaction. Journal of Verbal Learning and Verbal Behavior, 1971, 10, 316-321.

WOOD, G. (Michigan State University, East Lansing, Mich. 48823). Organization, large memory units, and free recall. Journal of Verbal Learning and Verbal Behavior, $1971,10,52-56$.

\section{CURRENT LITERATURE ON THE LOWER SENSES}

ANDERSON, N. H. (University of California, La Jolla, Calif. 92037). Text of adaptation-level theory as an explanation of a recency effect in psychophysical integration. Journal of Experimental Psychology, 1971, 87, 57-63.

DAY, R. H. (Monash University, Clayton Victoria, 3168, Australia), $\&$ WONG, T. S. Radial and tangential movement directions as determinants of the haptic illusion in an L figure. Journal of Experimental Psychology, 1971, 87, 19-22.

GREGSON, R. A. M. (Department of Psychology and Sociology, University of Canterbury, Christchurch, New Zealand), \& SIMMONDS, M. B. Qualitative gustatory characteristics of disodium-5'-guanylate. British Journal of Psychology, 1971, 62, 81-88.

HINTZ, J. M. (University of Alberta, Edmonton, Alberta, Canada), \& NELSON, T. M. Haptic aesthetic value of the golden section. British Journal of Psychology, 1971, 62, 217-223.

MARTINEZ, F. (Institut de Neurophysiologie et Psychophysiologie, Centre National de la Recherche Scientifique, Marseille, France). Comparison of two types of tactile exploration in a task of mirror-image recognition. Psychonomic Science, 1971, 22, 124-125.

McFARLAND, R. A. (California State College, Fullerton, Calif. 92631). Enhancement of thermal estimates by concomitant pressure stimulation. Journal of Experimental Psychology, 1971, 88, 20-25.

MITCHELL, M. J. (University of Canterbury, Christchurch 1, New Zealand), \& McBRIDE, R. L. Effects of propanol masking odor on the olfactory intensity scaling of eugenol. Journal of Experimental Psychology, 1971, 87, 309-313.

MOTTRAM, J. (Macquarie University, North Ryde, New South Wales 2113, Australia), \& SINGER, G. Judgments of body and object verticality in the presence of discordant visual information. Psychonomic Science, 1971, 22, 365-367.

REASON, J. T. (University of Leicester, Leicester, England), \& GRAYBIEL, A. The effect of varying the time interval between equal and opposite Coriolis accelerations. British Journal of Psychology, 1971, 62, 165-173.

SMITH, D. V. (Rockefeller University, New York, N.Y. 10021). Taste intensity as a function of area and concentration: Differentiation between compounds. Journal of Experimental Psychology, 1971, 87, $163-171$.

VERRILLO, R. T. (Laboratory of Sensory Communication, Syracuse University, Syracuse, N.Y. 13210), \& CHAMBERLAIN, S. C. Direct scaling of vibrotaction: An individual replication. Psychonomic Science, 1971, 22, 225-226.

WADE, N. J. (University of Dundee, Dundee, Scotland), \& SCHÖNE, H. The influence of force magnitude on the perception of body position. British Journal of Psychology, $1971,62,157-163$.

WOLFGANG, A. (Department of Applied Psychology, Ontario Institute for Studies in Education, 252 Bloor Street West, Toronto 181, Ontario, Canada). Errors and latency of response as a function of order of presentation of tactile-visual stimuli in concept identification. Psychonomic Science, 1971, 22, 237-238. 
BRAND, J. (Institute of Experimental Psychology, Oxford University, Oxford, England). Classification without identification in visual search. Quarterly Journal of Experimental Psychology, 1971, 23, 178-186.

CLEMENT, D. E. (University of South Florida, Tampa, Fla. 33620), \& HOSKING, K. E. Scanning strategies and differential sensitivity in a visual signal detection task: Intrasubject reliability. Psychonomic Science, 1971, 22, 323-324.

CLEMENT, D. E. (University of South Florida, Tampa, Fla. 33620), \& SCHIERECK, J. J. Scanning strategies and differential sensitivity in a visual signal detection task: Intersubject consistency. Psychonomic Science, 1971, 23, 385-387.

ELY, D. J. (Porterville State Hospital, Porterville, Calif. 23257). A comment on the Yaremko, Blair, and Leckart report: "The orienting reflex to changes in a conceptual stimulus dimension." Psychonomic Science, 1971, 23, 414.

EVANS, D. R. (University of Calgary, Calgary, Alberta, Canada), \& DAY, H. I. The factorial structure of responses to perceptual complexity. Psychonomic Science, 1971, 22, 357-359.

HOUSTON, B. K. (University of Kansas, Lawrence, Kans. 66044). Noise, negative transfer, and meaningfulness. Psychonomic Science, 1971, 22, 255-256.

MILLS, J. (University of Missouri, Columbia, Mo. 65201), \& O'NEAL, E. Anticipated choice, attention, and halo effect. Psychonomic Science, 1971, 22, 231-233.

O'GORMAN, J. G. (University of Queensland, St. Lucia, Queensland 4067, Australia). Habituation of the orienting reaction as a function of stimulus information. Psychonomic Science, 1971, 22, 331-332.

RASKIN, L. M. (Department of Child Development and Family Life, Purdue University, Lafayette, Ind. 47907), FONG, L. J., \& BLACK, K.
N. Perceptual recognition and guessing behavior by normal and educable retarded children. Psychonomic Science, 1971, 22, 371-372.

SANFORD, A. J. (The University, Dundee DD $14 \mathrm{HN}$, Angus, Scotland), \& MAULE, A. J, Age and the distribution of observing responses. Psychonomic Science, 1971, 23, 419-420.

TREISMAN, A. M. (Department of Experimental Psychology, Oxford University, Oxford, England). Shifting attention between the ears. Quarterly Journal of Experimental Psychology, 1971, 23, 157-167.

YAREMKO, R. M. (San Diego State College, San Diego, Calif. 92115). Reply to Ely. Psychonomic Science, 1971, 23, 414-415.

SHAFFER, L. H. (University of Exeter, Exeter, Devon, England). Attention in transcription skill. Quarterly Journal of Experimental Psychology, 1971, 23, 107-112.

\section{CURRENT LITERATURE ON VERBAL PROCESSES}

COREN, S. (New School for Social Research, New York, N.Y. 10011), \& SCHULMAN, M. A. Effect of an external stress on commonality of verbal associates. Psychological Reports, 1971, 28, 328-330.

DAMIANOPOULOS, E. N. (University of Iowa, Lowa City, Iowa 52240). Stimulus and response availability in associative learning. American Journal of Psychology, 1971, 84, 12-22.

DELPRATO, D. J. (Eastern Michigan University, Ypsilanti, Mich. 48197). Specific-pair interference on recall and associative-matching retention tests. American Journal of Psychology, 1971, 84, 185-193.

FORSTER, K. I. (Monash University, Clayton, Victoria, Australia 3168), \& RYDER, L. A. Perceiving the structure and meaning of sentences. Journal of Verbal Learning \& Verbal Behavior, 1971, 10, 285-296.

GIBSON, E. J. (Cornell University, Ithaca, N.Y. 14850), \& GUINET, L.
Perception of inflections in brief visual presentations of words. Journal of Verbal Learning \& Verbal Behavior, 1971, 10, 182-189.

HAMILTON, H. W. (Johns Hopkins University, Baltimore, Md. 21218), \& DEESE, J. Comprehensibility and subject-verb relations in complex sentences. Journal of Verbal Learning \& Verbal Behavior, 1971, 10, 163-170.

JOHNSON, G. J. (University of British Columbia, Vancouver, British Columbia, Canada). Transfer as a function of paradigm and interspersed-pair difficulty. American Journal of Psychology, 1971, 84, 276-287.

KAMMANN, R. (Bell Laboratories, Holmdel, N.J. 07733), \& STREETER, L. Two meanings of word abstractness. Journal of Verbal Learning \& Verbal Behavior, $1971,10,303-306$.

MARTIN, E. (University of Michigan, Ann Arbor, Mich. 48104), \&
CAREY, S. T. Retroaction, recovery, and stimulus meaningfulness in the $A-B, A-B r$ paradigm. American Journal of Psychology, 1971, 84, 123-133.

MARTIN, J. E. (Pennsylvania State University, University Park, $\mathrm{Pa}$. 16802), KOLODZIEJ, B., \& GENAY, J. Segmentation of sentences into phonological phrases as a function of constituent length. Journal of Verbal Learning \& Verbal Behavior, 1971, 10, 226-233.

REYNOLDS, R. J. (University of Georgia, Athens, Ga. 30601), BICKLEY, A. C., CHAMPION, S., \& DEKLE, O. Psychological Reports, 1971, 28, 211-215.

SASSON, R. Y. (Laboratoire de Psychologic experimental de la Sorbonne, 28 rue Serpente, 75 Paris 6 , France). Semantic organizations and memory for related sentences. American Journal of Psychology, 1971, 84, 253-267. 